\title{
Forord NTfK 100 år
}

Kære læser! På forsiden af dit tidsskrift vil du opdage, at der står årgang 100. I 1913 udkom for første gang Nordisk Tidsskrift for Strafferet, senere omdøbt til Nordisk Tidsskrift for Kriminalvidenskab. Det er ikke uden en vis stolthed, at vi markerer tidsskriftets jubilæum. I tidsskriftet kan man læse, hvad der gennem 100 år har rørt sig i strafferetten og kriminologien i de nordiske lande. Det er dog noget!

Tidsskriftet vidner også om det kriminalvidenskabelige samarbejde i Norden, om kriminalpolitiske tendenser, om nordisk debat og diskussioner fra 1913-2013. Det er jo temmelig enestående. Men hvem læser 100 årgange i ét stræk? Næppe mange, om nogen. Vi har derfor bedt Peter Garde skrive en artikel om de 100 år. Han er, mere end nogen anden, en person, som kan gøre netop det. Han har valgt en model, hvor konklusionerne i høj grad er overladt til læseren selv, men hvor det er muligt på kort tid - takket være hans indsats - at danne sig et overblik og en mening. Den, der vil, kan med artiklen ved hånden dykke ned i tider og tendenser, hints om skandaler og personalhistorie, fremhævelse af skarp kritik og videnskabelige højdepunkter fra før 1. verdenskrig til længe efter mobiltelefonens og internettets opfindelse. Her afspejles strafferetten i efterkrigstiden, behandlingstankens storhed og fald, debatten om proportionalitetsprincippet og »law and order«, terrorismelovgivningens højkonjunktur og tiden efter. God fornøjelse!

Og så markerer de 100 år den teknologiske udvikling. I disse dage lægges alle 100 årgange ind på Det Kongelige Biblioteks server og bliver dermed (for evigt?) online tilgængeligt for hele verden. Databasen bliver vedligeholdt af Det Kongelige Bibliotek. Der sørges for, at søgninger i Google m.v. giver hits fra basen. Nye tider. Den nye online tilgængelighed i kombination med stærkt forøgede portoudgifter gør det tvivlsomt, om tidsskriftet i papirform overlever de næste 100 år. Så nyd nu også vægten af den trykte udgave i hånden, ved natbordet, sofabordet, arbejdsbordet, toiletbordet.

Thomas Elholm, hovedredaktør

Odense den 21. februar 2013 